\title{
Aleksandra Kosicka-Pajewska
}

\section{Dramatyczność kolorów historii}

ABSTRACT. Aleksandra Kosicka-Pajewska, Dramatyczność kolorów historii [The dramatic colors of history]. „Przestrzenie Teorii” 36. Poznań 2021, Adam Mickiewicz University Press, pp. 57-71. ISSN 1644-6763. DOI 10.14746/pt.2021.36.3.

The drama of Katyń. The theory of colors, Julia Holewińska based on Józef Czapski's Old Bielsko Memories, although largely processed. The protagonist of the play is Józef Czapski, a painter-capist, writer, intellectual, prisoner of Starobielsk, Pawliszczew Boru, Griazowiec, who builds his paintings in the performance with colors. The setting for these events is Kozielsk, where the artist was not held, which proves that this is not Czapski's biography, nor is it a documentary account of camp life. The playwright, on the basis of a harsh and humiliating reality, showed human sensitivity. In Holewińska's drama, Czapski acts as a guide through the camp experience through the eyes of a colorist. In each sequence, the artist expresses his view of color in art. There are two more allegorical characters in the drama: Our Lady of Kazan, who embodies three beings: Our Lady of Kazan (The Blessed Virgin of Kazan) - as the sacred, the real pilot Janina Lewandowska, and femininity in general. The second allegorical figure is the great Katyn liar, who personifies the whole apparatus of repression and oppression of the NKVD. The background for the conversations between these characters is a two-person choir - one out of a thousand and the Second of thousand. Art of Katyń. The theory of colors is devoted to painful historical events, despite the fact that it is subject to various playwriting procedures, it is moving in its meaning.

KEYWORDS: Katyń, Józef Czapski, Janina Lewandowska, colors, humiliation, drama, murder

Związek między historią a literaturą od najdawniejszych czasów znajdował się w sferze zainteresowań historyków, literaturoznawców, dramatopisarzy. Renon Teine uważał, że „historia jest sztuka, a zarazem historia””. Zdaniem Marcelego Handelsmana różnica między historią a sztuką „polega na tym, że pierwsza odtwarza tylko tę część rzeczywistości minionej, której istnienie zostało uprzednio ustalone na gruncie dokumentów, kiedy sztuka odtwarza rzeczy wyczute lub przeczute w rzeczywistości; pierwsza dąży do odtworzenia rzeczywistości konkretnej, druga - do tworzenia typów, posiadających własne, niezależne od tej rzeczywistości życie”2. Historia inspirowała licznych twórców; na podstawie prawdziwych wydarzeń powstało wiele powieści, dramatów i filmów (m.in. Powstanie warszawskie, Kanat, Godzina W, Miasto 44).

Dla współczesnego pokolenia doświadczenia z przeszłości mają szczególne znaczenie. Pamięć historyczna w teraźniejszości nabrała przyspieszenia

${ }^{1}$ Cyt. za: M. Handelsman, Historyka, oprac. P. Węcowski, reprint, wyd. 2 rozszerzone, Warszawa 2010, s. 27.

${ }^{2}$ Ibidem, s. 27-28. 
historii i w pewien sposób wymyka się nam z pola widzenia. Najważniejszymi sposobami „magazynowania” pamięci są pisanie książek, tworzenie dokumentów, filmów, sztuk teatralnych.

Pisanie jest nie tylko sposobem na utrwalenie nieśmiertelności, wspomaga także pamięć. Proces pisania na czymś albo wpisywanie czegoś w coś jest najstarszą i mimo długiej historii wszystkich mediów - wciąż najbardziej wyrażoną metodą pamięci³

Dzieła literackie, literatura dokumentu sa jak ślad, który odsyła czytelnika do warstwy pozatekstowej, ale „odczytywany jest za pomocą systemu semiotycznego". A więc teksty mogą odgrywać podwójną rolę wobec pamięci „są śladami przeszłości i zarazem "schowkiem», w którym sa gromadzone wspomnienia"4. Literatura zawiera w sobie wielowątkowość form literackich, a jednym z mediów pamięci jest pamięć zbiorowa. Pamięć zbiorowa możemy rozumieć na dwa sposoby: jako pamięć zgromadzona, czyli pamięć, na którą składają się indywidualne wspomnienia określonych osób ujęte i uporządkowane w wyznaczone ramy społeczne, lub taką która wykracza poza ograniczenia pamięci indywidualnej.

Ludobójstwo i polityka terroru podczas II wojny światowej zostały bogato udokumentowane w postaci opracowań naukowych oraz cennych relacji osobistych. Ocalałe pamiętniki, spisane wspomnienia osobiste odgrywaja ważną rolę poznawczą i moralną dla ocalenia prawdy tych wydarzeń. Literatura oparta na osobistych przeżyciach jako dokument historyczny jest ważnym świadectwem polityki pamięci. Veronica Tozzi pisze:

Taka strategia, przyjmując nową epistolografię świadectwa, zakłada traktowanie świadectwa nie tyle jako podróży w przeszłość, ile jako czynności w czasie teraźniejszym, która ma na celu uświadomienie, po pierwsze, iż wiara w świadectwo jest podstawowym warunkiem zaakceptowania wiedzy - świadectwa nie są wtórnymi wiedzy czy pasożytowaniem na doświadczeniu i rozumie - oraz po drugie, że tworzenie i cyrkulacja świadectw odgrywa ważną rolę nie tylko w ocenie materiałów, lecz także prawomocnie konstytuuje wiedzę ${ }^{5}$.

Istnieje w dziejach Polski wiele wydarzeń z przeszłości utrwalonych na kartach powieści, dramatów, a także w obrazach filmowych, na potrzeby których przetwarza się dokument osobisty w sposób odpowiedni dla teraźniejszości i przyszłości. Polityka pamięci jest bowiem tym tworzywem,

${ }^{3}$ A. Assmann, Curtural Memory and Western Civilizacion, Cambridge 2011, s. 174.

${ }^{4}$ J. Tabaszewska, Kategoria pamięci kulturowej w badaniach nad literatura, „Pamiętnik Literacki” 2013, CIV, z. 4, s. 55.

${ }^{5}$ V. Tozzi, Przywileje świadectwa. Historia, pamięć i literatura w sporach o konstruowanie nieodlegtej przeszłości, przeł. E. i J. Zięba, „Teksty Drugie” 2010, s. 12. 
które jest otwarte na inne symboliczne, nietekstualne sposoby wyrażania upamiętnienia ofiar.

Istnieje w dziejach Polski wiele wydarzeń, które w pamięci narodowej zajmują miejsce wyjątkowe, miejsce szczególne. Jednym z nich jest ludobójstwo polskich oficerów w Katyniu i innych miejscach kaźni.

W świadomości zbiorowej narodu polskiego mord w Katyniu jest zakorzeniony bardzo głęboko. Od chwili odkrycia grobów w 1943 roku aż do roku 1989 ze względów politycznych był zacierany i zakłamywany (niezbyt skutecznie). W kwietniu 1940 roku ponad 22000 polskich jeńców z obozów NKWD zostało rozstrzelanych w Lasku Katyńskim niedaleko Smoleńska ${ }^{6}$. Decyzja o „zlikwidowaniu” polskich jeńców wojennych zapadła 5 marca 1940 roku na najwyższych szczeblach władzy radzieckiej. Autorem wniosku o rozstrzelanie Polaków bez sądu był Ławrientij Beria - ludowy komisarz spraw wewnętrznych. Pod dokumentem akceptującym żądanie zagłady podpisali się Stalin, Woroszyłow, Mołotow, Mikojan, a dopisali się Kalinin oraz Kaganowicz. W dokumencie Beria podkreślił, że zatrzymani Polacy to zawzięci wrogowie ZSRR, nierokujący nadziei na jakąkolwiek poprawę. Niektórzy historycy twierdza, że był to także akt zemsty za rok 1920.

Mord w Katyniu to akt zbrodni, zbrodni masowej, zbrodni ludobójstwa. Niemcy w 1943 roku w chwili odkrycia grobów oczekiwali pogorszenia się stosunków ZSRR z aliantami zachodnimi. Tak się nie stało. Stalin wyzyskał ten fakt jako pretekst do zerwania stosunków dyplomatycznych między rządem polskim w Londynie a rządem sowieckim. Churchill zmarginalizował znaczenie Polski jako alianta.

Kłamstwo katyńskie ma długa historię. Zaczęło się w chwili odkrycia grobów w kwietniu 1943 roku. Kłamać zaczęli Niemcy, chcący wyzyskać ten fakt propagandowo. Po pierwszych komunikatach Moskwy o odkryciu grobów do kłamstwa dołączyli Sowieci. W grudniu 1941 roku podczas rozmów na Kremlu Stalin przekonywał Sikorskiego i Andersa, że polscy jeńcy uciekli do Mandżurii. Fundamentem tzw. sowieckiego kłamstwa katyńskiego stał się dokument przygotowany przez komisję Burdenki. Konkluzja raportu brzmiała, że masowych rozstrzeliwań Polaków w Lesie Katyńskim dokonał niemiecki urząd wojenny pod nazwa „Sztab 537 batalionu roboczego”. Zbrodnia katyńska była wymierzona nie tylko w ludzi zamordowanych, lecz także w prawdę. Przez kolejne pół wieku władze PRL nakazywały milczeć o tej potwornej zbrodni. Dopiero w roku 1990 ZSRR przyznał się do mordu, chociaż do dzisiaj Rosja nie ujawniła wszystkich dokumentów; nie znamy pełnej listy nazwisk Polaków zamordowanych „na nieludzkiej ziemi”.

${ }^{6}$ Zlokalizowano: w obozie w Kozielsku - żołnierzy; w Ostaszkowie - policjantów; w Starobielsku - żołnierzy i przedstawicieli innych służb. 
$\mathrm{Na}$ temat Katynia powstała bogata naukowa literatura historyczna ${ }^{7}$. Zachowały się zapiski osobiste odnalezione przy zamordowanych oficerach podczas ekshumacji, pisane na skrawkach papieru; stąd mamy obszerna wiedzę o wydarzeniach z 1940 roku. Swoje wspomnienia z pobytu w Starobielsku w formie dokumentu osobistego spisał Józef Czapski - Na nieludzkiej ziemi (częścią sa Wspomnienia starobielskie oraz z Kozielska). Stanisław Swianiewicz napisał W cieniu Katynia. W latach pięćdziesiątych XX wieku powstał film dokumentalny o zbrodni katyńskiej, w którego przygotowaniu uczestniczył Władysław Cichy - były więzień Griazowca i Kozielska. Razem z dr. Władysławem Sthalem napisał on komentarz do obrazu; ten ostatni wystapił w nim w roli lektora ${ }^{8}$.

Od zakończenia wojny aż do 1990 roku nie powstały ani film fabularny, ani polska powieść o tematyce katyńskiej. Powodem nie była cenzura, bowiem wielu twórców kina i powieściopisarzy mieszkało poza krajem i zakazy ich nie obejmowały. Trudność, jak twierdzi Andrzej Wajda, „leżała w samym temacie".

Zasadniczą treścią dzieł artystycznych o Katyniu sa „tajemnica i kłamstwo", przemilczane przez blisko 50 lat. Dopiero Andrzej Wajda w 2007 roku stworzył film Katyń. Opowiada w nim nie o zamordowanych, nie o ofiarach, ale o rodzinach „rozłączonych na zawsze”, o prawdzie, o uczuciach. Osobiste doświadczenia reżysera - obserwacja matki, ciagle czekającej na swojego męża, niepogodzonej z tym, że nie wrócił on z wojny - stworzyły strukturę opowieści filmowej Wajdy o Katyniu. Wajda pisze:

Pamiętam dobrze niepokoje, nadzieje i rozpacz Matki, która do końca swego życia w 1950 roku oczekiwała znaku od ojca - jeńca obozu w Starobielsku. [...] Z tych względów widzę mój film o Katyniu jako opowieść o rodzinie rozłączonej na zawsze, o wielkich złudzeniach i brutalnej prawdzie ${ }^{10}$.

$\mathrm{Na}$ deskach teatru dotąd nie wystawiono sztuki poświęconej problematyce katyńskiej. Izolacja w 2020 roku zainspirowała Julię Holewińska do napisania dramatu pt. Katyń. Teoria barw.

Dramatopisarka zaproponowała inną formę opowieści o Katyniu od filmowej autorstwa Wajdy. Bohaterem dramatu jest Józef Czapski, malarz

${ }^{7}$ O Katyniu pisali m.in.: W. Wasilewski, Mord w lesie katyńskim. Przestuchania przed amerykańska komisja Meddena w latach 1951-1952, t. 1, Warszawa 2017, t. 2, Warszawa 2018; idem, Ludobójstwo, ktamstwo i walka o prawdę. Sprawa Katynia 1940-2014, Łomianki 2014; Zbrodnia Katyńska w świetle dokumentów, przedm. W. Anders, wyd. 1, Londyn 1948.

${ }^{8}$ T. Walasza, Filmy katyńskie 1943-1953, „Wojna i Pamięć” 2019, nr 1.

${ }^{9}$ Katyń, Andrzej Wajda o filmie, http:/www.wajda.pl/pl/filmy/katyn.html (dostęp: 2.05.2021).

${ }^{10}$ Ibidem. 
kapista, pisarz, intelektualista, więzień Starobielska, Pawliszczewa Boru oraz Griazowca, który swoje obrazy w sztuce buduje kolorem. Do niewoli radzieckiej dostał się on 27 września 1939 roku, w październiku trafił do obozu jenieckiego w Starobielsku, w którym przebywał do maja 1940 roku. W kwietniu wywieziono stamtąd większość więźniów. Zamordowano ich w Charkowie. Czapskiego przed rozstrzelaniem uratowało niemieckie pochodzenie.

Dramat Holewińskiej jest oparty na Wspomnieniach starobielskich Józefa Czapskiego, chociaż w dużym stopniu został przetworzony. Miejscem wydarzeń jest Kozielsk, w którym artysta nie przebywał, co świadczy o tym, że sztuka nie jest biografią Czapskiego ani dokumentalna relacja wydarzeń obozowych. Jest dramatem, który na kanwie historycznej, ciężkiej rzeczywistości pokazuje wrażliwość człowieka o wyjątkowej subtelności intelektualnej. W starobielskim obozie podobna psychikę miało wielu jeńców.

Czapski - malarz posłużył Holewińskiej do zbudowania dramatu Katyń. Teoria barw. Artysta odgrywa rolę przewodnika po doświadczeniu obozowym widzianym oczami kolorysty. Dramatopisarka czasami przytacza dosłowne wypowiedzi zawarte w tekście Wspomnień starobielskich, a niekiedy odbiega od tekstu całkowicie. W każdej sekwencji Czapski wypowiada swój pogląd na sztukę, a dokładniej - na kolor w niej.

W dramacie występuja jeszcze dwie postacie alegoryczne: Matka Boska Kazańska (która zawiera w sobie trzy role: Matkę Boską Kazańska, pilotkę Janinę Lewandowską i ogólnie kobiecość) oraz Wielka Kłamczucha Katyńska, uosabiająca cały aparat represji i ucisku NKWD. Tłem dla rozmów wymienionych postaci jest dwuosobowy chór - Jeden z Tysięcy i Drugi z Tysięcy - który określa także chronologię wydarzeń.

Dramat Katyń. Teoria barw został podzielony na sekwencje oznaczone w większości kolorami: Istota piękna, Paleta barw, Biaty, Niebieski, Czerwony, Szary, Zielony, Żótty, Czarny, Ślepnac. Sekwencje nazwane określoną barwą nie sa przypadkowe; przedstawiają problem z obozowego życia, a krótki wykład teoretyczny Czapskiego o kolorze w sztuce, który wydaje się całkowicie oderwany od realiów, trafia w samo sedno sytuacji jeńców.

Nauka o barwach ma długa historię - sięga wielowiekowej tradycji filozoficznej, artystycznej i psychologicznej.

Psychologia jako samodzielna nauka odziedziczyła po tradycji malarskiej wszelkie teorie i praktyki związane z percepcją kolorów, ekspresją poprzez działania artystyczne. Dzięki wykorzystaniu w badaniach psychologicznych tradycji malarskiej można wzbogacić wiedzę dotycząca procesu twórczego, a także podkreślić znaczenie oddziaływania zjawisk barwnych na psychikę ${ }^{11}$.

${ }^{11}$ E. Szkudlarek, Portrety cieni Witkacego, Poznań 2017, s. 260. 
Teorią barw zajmowało się wielu uczonych, filozofów, fizyków, malarzy, a także poetów, m.in. I. Newton, G.W.F. Hegel, E. Delacroix, Ch. Baudelaire, J.W. Goethe. Newton do wiedzy ogólnej wniósł pogląd, że wszystkie barwy sa zawarte w świetle białym, w świetle stanowiącym źródło światła. Z widma światła białego pochodzi kwantyfikacja mieszana, z której wynikaja proporcje barw. Goethe natomiast twierdził, że w procesie tym są ważne otoczenie zewnętrzne i powierzchnia, na którą pada światło. Kolor był dla niego związany ze sfera emocjonalna, a nie wzrokowa. Teoria estetyczna niemieckiego poety oparta na obserwacji głosiła, że kolory powstają ze światła i z ciemności ${ }^{12}$. Percepcja koloru i światła, ich wpływ na „kondycję ludzkiej psychiki” są związane ze stanem zarówno fizycznym (zachwyt samym kolorem), jak i psychicznym (odbiór emocjonalny koloru). Badania nad znaczeniem symbolicznym i ideologicznym kolorów zawsze wymagają konfrontacji z wiedzą naukową i odbiorca. Kolor w XX wieku zajmował uwagę wielu malarzy. Barwa stała się dla nich nieuchwytnym drganiem - siłą wewnętrzną oddziałującą na artystę i widza. Do uznanych kolorystów należeli polscy malarze zgrupowani wokół Pankiewicza, m.in. Józef Czapski. Kolor dla Czapskiego był głęboką emocja, obiektem intelektualnej analizy, którą wyzyskała Julia Holewińska do budowy wypowiedzi artysty w sztuce dramatycznej. Czapski rozpoczyna dramat krótkim wykładem o tym, czym jest „istota piękna”:

\begin{abstract}
Nowe widzenie natury - mówi. - Operowanie kolorami czystymi. Gama barwna o niezmiernej światłości i natężeniu. Najważniejszym tematem jest pejzaż, światło i pogoda. Lasy buchają zielenią. Słońce spala się do czerwoności i gaśnie. Chmury tańczą w świetlnej wibracji. [...] Plama barwna jest podstawowym elementem konstrukcji. Konstrukcji obrazu i świata. Kiedy kolor jest u szczytu bogactwa, wtedy forma osiaga pełnię. Wtedy doświadczamy piękna ${ }^{13}$.
\end{abstract}

Tym słowom o istocie piękna Holewińska przeciwstawiła warunki, w jakich znaleźli się jeńcy. Słowa artysty są całkowicie oderwane od rzeczywistości. Artysta wzięty do niewoli znalazł się w twardych, upokarzających obozowych warunkach. Rozpoczęła się szara, monotonna codzienność: brak intymności, zatłoczony monastyr zaadaptowany na potrzeby mieszkalne jeńców, bród, wszy i przenikliwe zimno. Czapski w dramacie wypowiada ważne słowa zaczerpnięte ze Wspomnień starobielskich: „Tutaj żyliśmy w tłoku. Brak samotności ciążył nam bardziej niż głód i wszy"14. To trudne doświadczenie dla wielu jeńców (osadzonych nie tylko w Starobielsku) było ciężkim

${ }^{12}$ J.W. Goethe, Nauka o barwach, przeł. E. Namowicz, [w:] idem, Wybór pism estetycznych, wyb., oprac. i wstęp T. Namowicz, Warszawa 1981, s. 315; J. Gage, Kolor i znaczenie, sztuka, nauka i symbolika, przeł. J. Holzman, A. Żakiewicz, Kraków 2010, s. 172.

${ }^{13}$ J. Holewińska, Katyń. Teoria barw, „Dialog” 2020, nr 12, s. 14.

${ }^{14}$ J. Czapski, Wspomnienia starobielskie, [w:] Na nieludzkiej ziemi, Warszawa 1990, s. 20. 
przeżyciem; nigdy nie można było pobyć w samotności, widywało się natomiast rozprężenie, upadek moralny, który część ludzi zamienił w „szmaty”. Istota piękna została zniszczona i zredukowana do zera. „Kolory mieszaja się. Czarna wesz, krew czerwona, niebo szare" - konstatuje Czapski ${ }^{15}$.

W sekwencji Niebieski Holewińska przytacza rzeczywiste słowa Czapskiego ze Wspomnień starobielskich:

Wieloletnia praca malarska rozwinęła we mnie w ostatnich latach przed wojna bardzo żywy i właściwie stały stosunek do natury. Niezależnie od malowniczości, najprościej reagowałem na światło, na drzewa, na chmury czy mury. Ale od września przez szereg tygodni miałem wrażenie zupełnego zerwania kontaktu z natura, odcięcia od natury. Najpiękniejszy zachód słońca, najdziwniejszy widok, wszystko było mi całkowicie obce. Dlatego tak bardzo utkwił mi w pamięci pierwszy przeżyty na nowo pejzaż. Był już koniec listopada, o wschodzie słońca za czerwonymi murami naszego budynku nagle „wybuchnęło” bengalskie niebo pełne różowych, błyskających, jakby elektrycznych chmur, przetykanych smugami ostrego lazuru. Na tym tle wielkie, nowo zbudowane ogrodzenie z potężnych spiczastych pali świeciło rudozłotym światłem, budka drewniana, nieoświetlona promieniami słońca, miała kolor szafiru, a poza ogrodzeniem z daleka widać było wielkie drzewa o jasnoniebieskich jaśniejszych niż niebo pniach, okryte, nanizane tysiącami czarnych kawek i wron. Potem z tygodnia na tydzień pomału wracało przeżywanie kształtów i barw. Był to znak powolnego powrotu do życia, nawet do radości życia, wbrew wszystkiemu ${ }^{16}$.

Kolor niebieski w tradycji malarskiej jest przypisywany duchowości, chociaż każdy odbiorca widzi tę barwę inaczej. Istotą jednak jest metafizyka samego koloru niebieskiego. Kandinsky pisze:

[...] błękit jest typowym kolorem niebios. Błękit w swoich najniższych głębiach rozwija element spokoju. Kiedy przechodzi w czerń, przyjmuje tony nadludzkiego smutku. Staje się jak nieskończone samo zaangażowanie w ten dogłębny stan powagi, kiedy nie ma i może nie mieć końca ${ }^{17}$.

Błękit może być też barwą uprzywilejowaną dla pewnych struktur psychicznych. Estetyzm i wiedzę o kolorze Czapski zawsze łączy z brutalną rzeczywistością. Sekwencja Niebieski wyznacza jeńcom kolejny okres spędzony w obozie. Przesłuchania, zagrożenia, smutek. „Zamiast nieba widzę siniaki" - mówi Czapski.

Część dramatu oznaczona kolorem białym oznajmia przybycie do obozu „bezdenna otchłań nieskończoność przed nami”. Biel często jest uważana za

\footnotetext{
${ }^{15}$ J. Holewińska, op. cit., s. 17.

${ }^{16}$ J. Czapski, op. cit., s. 35; J. Holewińska, op. cit., s. 21.

${ }^{17}$ Cyt. za: J. Gage, op. cit., s. 192.
} 
niekolor. Ujmuje się ją jako symbol świata, w którym zniknęły wszystkie właściwości substancji materialnych. Jest jak milczenie, które może nagle zostać zrozumiane ${ }^{18}$. Spośród wielu rodzajów bieli biel ołowiana jest najniebezpieczniejsza, bo trująca, a biel tytanowa najlepsza - i to do niej Czapski przyrównuje położenie więźniów obozu, zrozpaczonych, bez realnych możliwości zmiany położenia, zmiany swojego losu. „Białe kłamstwa - mówi. Pogrzeb malarstwa. Pogrzeb Polski. [...] Zamknęli nas tu jak psy"19.

Szarość to kolor smutku, kolor popiołu. Powstaje ze zmieszania bieli i czerni. Tak uzyskany kolor nie ma ekspresji ani ruchu. Szarość jest „nieruchoma”, bez nadziei. Im bardziej ciemnieje, tym więcej rozpaczy, ale wystarczy dodać bieli, by wydobyć z niej kolor nadziei. W obozowej rzeczywistości znaczyła codzienną monotonię, niepokój, nerwowość o bliskich w Polsce. W niewoli wszyscy byli równi w swojej szarej masie, położeniu, bez jakiejkolwiek perspektywy na przyszłość, ale z aktualnym pytaniem, co będzie dalej.

Kolor czerwony rzadko występuje w naturze. Uznaje się, że czerwień jest kolorem miłości, kolorem kobiecości. Maria Rzepińska pisze:

Bez wątpienia czerwień jest w mentalności prymitywnej bardzo uprzywilejowana, przy czym dotyczy to całej ludzkości. Wiąże się ona przede wszystkim z kolorem krwi, wojny, ognia, siły, płodności, potęgi, ale także ofiary, dostojeństwa, godności królewskiej $^{20}$.

Czerwień pojmujemy abstrakcyjnie. Jest rezonansem wewnętrznym, z jednej strony precyzyjnym, z drugiej - nieprecyzyjnym, niezdecydowanym. Czapski pyta, czy miłość do ojczyzny, walka o nią homoseksualisty i heteroseksualisty są takie same. I odpowiada - krew przelana za Polskę ma taką samą czerwoną barwę.

Zielony - to Boże Narodzenie w obozowej rzeczywistości. Jest kolorem nadziei, ale może też być kolorem trucizny, bowiem zieleń arszenikowa to najbardziej trująca zieleń. Czapski patrzy w przyszłość przez zielone szkiełko, które uspokaja, i marzy o tym, co będzie robił po wojnie. Szuka nadziei, której nie widzi; patrzy na „zielone twarze” współwięźniów. Brak nadziei na poprawę losu.

Sekwencja Żótty. Żółty to mieszanka zielonego i czerwonego. Oznacza rozpacz, beznadziejność. Zamiast koloru Czapski widzi chorobę, a żółte ciała współwięźniów dają ostatnie znaki życia, bowiem potem następuje śmierć.

${ }^{18}$ M. Rzepińska, Historia koloru w dziejach malarstwa europejskiego, Warszawa 2009, s. 129.

${ }^{19}$ J. Holewińska, op. cit., s. 20.

${ }^{20}$ M. Rzepińska, Studia z teorii i historii koloru, Kraków 1966, s. 100. 
Kolor czarny jest kolorem śmierci. Czapski unika tej barwy, a mimo to stale o niej myśli, jest ona w jego snach. „Czarna perła. Koniec jest czarny” kończy sekwencję artysta ${ }^{21}$.

W wypowiedziach Czapskiego w dramacie kolor odgrywa rolę języka, który wyrażał rozmiar ludzkiego cierpienia. Życie codzienne nie obrazowało dramatyczności; było ciężkie, szare, monotonne, pełne bólu. Po latach Czapski napisze:

Utrzymywała mnie na wodzy [w obozach w Rosji - przyp. A.K.-P.] świadomość, że nie umiem rysować, nie umiem malować, pochłaniało mnie przezwyciężenie konkretnych trudności ${ }^{22}$.

Po wojnie Czapski nigdy nie namalował obrazu, którego tematem byłyby przeżycia obozowe. Malując, używał nasyconych barw i kontrastowych zestawień kolorystycznych. W ten sposób uzyskiwał efekt silnej ekspresji, a czasem groteski.

Wszystkie sekwencje artysty dopełnia chór, który stanowił tło dla „osobowości Czapskiego" ${ }^{23}$. Chór w dramacie stanowi kontrapunkt dla wypowiedzi Czapskiego. Jeden z Tysięcy i Drugi z Tysięcy to zbiorowy byt, który łączy rzeczywistość zewnętrzną i pozostałe postacie sztuki. Jest równoprawnym bohaterem, ma znacząca pozycję w międzysłownej relacji z pozostałymi osobami dramatu. Odgrywa rolę informacyjna, przedstawia realia obozowe, polowanie na pluskwy, mówi, na jakie choroby zapadali więźniowie, podaje jadłospis, pyta o warunki życia w Rosji. Chór „komentuje” aktualne wydarzenia polityczne - stwierdza: „W Paryżu utworzył się rząd polski”, „Marszałek nie dorósł do swego zadania”"24.

Chór w sztuce Holewińskiej przypomina „tradycyjne formy zbiorowej persony [...] i buduje polifoniczna formę dramatu" ${ }^{25}$. Jest dziełem otwartym, daje możliwość włączenia się w proces twórczy. Umberto Eco nazywa takie teksty „dziełami w ruchu” ${ }^{26}$. Chór tworzy także nastrój sztuki - od smutku do nadziei.

${ }^{21}$ J. Holewińska, op. cit., s. 43.

22 J. Czapski, Patrzqc, wyb., przedm. i posł. J. Polakówna, Kraków 2016, s. 93.

${ }^{23}$ M. Szpakowska, W kolorach, „Dialog” 2020, nr 12, s. 8.

${ }^{24}$ Mowa o marszałku Rydzu-Śmigłym, który opuścił Polskę jako naczelny wódz wraz z rządem 17 września 1939 roku.

${ }^{25}$ D. Szewczyk-Świerniak, Polifonie chóralności w najnowszym dramacie polskim, Katowice 2020, s. 30 (niedrukowana praca doktorska).

${ }^{26}$ U. Eco, Poetyka dzieła otwartego, [w:] idem, Dzieło otwarte. Forma i nieokreśloność w poetykach wspótczesnych, przeł. J. Gałuszka, Warszawa 1994, s. 25. 
Dialogi chóru w dramacie Holewińskiej podlegają stałej rytmizacji i w ten sposób budują poetyckie obrazy, które niszczą dramatyczność przedstawienia. Poetyckość widzimy m.in. w opisie drogi do Rosji:

Jeden z Tysięcy Pięknie.

Drugi z Tysięcy Boże, jak pięknie.

Jeden z Tysięcy Przepiękny poranek, w ogóle cudna pogoda.

Drugi z Tysięcy Śliczny dzień.

Jeden z Tysięcy Dzień cudownie jesienny.

Drugi z Tysięcy Na świecie pięknie.

Jeden z Tysięcy Cudne słońce - słonecznie, ciepło.

Drugi z Tysiąca Gorąco.

Jeden z Tysięcy Słodki dzień - pod znakiem cukru.

Drugi z Tysięcy Pyszne słońce ${ }^{27}$.

Innym razem dialogi z pozostałymi postaciami tworzą rodzaj poematu. Chór w dramacie Katyń. Teoria barw jako bohater zbiorowy jest figura statyczna. Edward Morgan Forster nazwał taki chór „monodymensjonalnym”, czyli takim, który objawia społeczno-polityczne aspekty swojego istnienia ${ }^{28}$.

Druga postacia „obcą” - podobna do Czapskiego - w dramacie Julii Holewińskiej jest Matka Boska Kazańska. To postać alegoryczna, która łączy w sobie trzy tożsamości: Matkę Boską Kazańska, pilotkę Janinę Lewandowską oraz ogólnie kobiecość. W dramacie, jak określiła M. Szpakowska, ,jest sui genesis czy analogonem Czapskiego" ${ }^{29}$. Holewińska zręcznie posługuje się wypowiedziami tych trzech tożsamości, przechodząc z jednej do drugiej. Każda z nich ma zadania do wypełnienia, a także swoje barwy.

Alegoria w dziele literackim jest wyrazem idei oraz ludzkich potrzeb wolności, poczucia bezpieczeństwa. Język dramatu jest jedynym składnikiem, który ma znaczenie i wpływa na interpretację alegorii, właściwe odczytanie sztuki. Alegorią będzie więc to, co zostało ustanowione dzięki interpretacji. Jak pisał J.W. Goethe:

Alegoria przekształca zjawiska w pojęcia, pojęcia zaś w obraz, ale tak, że pojęcie ciąle jeszcze powinno być wpisane, w całości w nim zachowane i powinno się przez ten obraz wyrażać ${ }^{30}$.

Innymi słowy alegoria zawiera się ściśle w obrazie, który ją wyraża, czyli oznacza precyzyjnie określone zjawiska. Inaczej symbol - jest trudniej-

\footnotetext{
${ }^{27}$ J. Holewińska, op. cit., s. 14.

${ }^{28}$ W. Baluch, M. Sugiera, J. Zając, Dyskurs, postać i pteć w dramacie, Kraków 2002, s. 198.

${ }^{29}$ M. Szpakowska, op. cit., s. 10.

${ }^{30}$ J.W. Goethe, Refleksje i maksymy, oprac. J. Prokopiuk, Warszawa 1977, s. 208.
} 
szy do jednoznacznego odczytania. Musimy także pamiętać o tym, że Goethe traktował sztukę jako przekazicielkę rzeczy niewypowiedzianych ${ }^{31}$. Za G.W.F. Heglem możemy dopowiedzieć, że aby uczynić ją abstrakcyjna znaczeniowo, alegoria musi ją „opustoszyć” z cech indywidualności ${ }^{32}$. Alegoria w sztuce Katyń. Teoria barw stanowi efekt celowego konceptualnego działania dramatopisarki, zmierzającego do jak najpełniejszego zilustrowania faktów i postaci.

Alegoryczna postacią w sztuce jest Matka Boska Kazańska. Na ikonę dramatu Holewińska wybrała Janinę Lewandowską która występuje pod postacią trzech bytów.

Pierwszy to sacrum - wizerunek Matki Boskiej Kazańskiej. Jest to jeden z najbardziej znanych wizerunków Maryi w Rosji, zwany Hodegetria, czyli przewodniczka, wskazującą drogę. Do tej kategorii należy także obraz Matki Boskiej Częstochowskiej. Ikona Matki Boskiej Kazańskiej ma długą i bogata historię. Dla jeńców polskich w obozach był to wizerunek obcy; obcy był także kulturze polskiej. Więźniowie w Kozielsku wykonali obraz Matki Boskiej Kozielskiej, z która przeszli cały szlak bojowy II Korpusu. Być może Holewińska chciała podkreślić obcość miejsca i sytuacji, w jakich znaleźli się polscy oficerowie.

W obozie w Ostaszkowie, o czym pisze Czapski we Wspomnieniach starobielskich, w Kozielsku i innych miejscach osadzeni księża odprawiali msze święte, odmawiano zbiorowe modlitwy. Alegoria w tym sensie to rozpoznanie ogólnej wymowy sacrum.

Bytem drugim, rzeczywistym, jest Janina Lewandowska - absolwentka konserwatorium, spadochroniarka, radiotelegrafistka, pilotka, która została zamordowana w Katyniu jako jedyna kobieta. Była córką gen. Józefa Dowbora-Muśnickiego. Została wychowana surowo, w tradycji wolnościowej. Z kartą mobilizacyjna i dwoma pistoletami, które dostała od ojca, zaledwie 50 dni po ślubie jako osoba cywilna wyruszyła na wojnę. Do niewoli sowieckiej dostała się już 22 września wraz z kapitanem Sidorem z 3. Bazy Lotniczej z Ławicy. Początkowo trafiła do Ostaszkowa. Już wówczas miała na sobie mundur podporucznika pilota ${ }^{33}$. W grudniu 1939 roku trafiła do

${ }^{31}$ Ibidem, s. 196.

${ }^{32}$ G.W.F. Hegel, Wyktady o estetyce, t. I, przeł. J. Grabowski, A. Landman, Warszawa 1964, s. 629.

${ }^{33}$ Nie do końca wiemy, dlaczego Janina Lewandowska nosiła mundur lotnika i trafiła do obozu dla wojskowych. Jej koledzy z aeroklubu zostali osadzeni w obozie przejściowym i nie trafili do Starobielska ani Kozielska. Naoczny świadek Teodor Łagoda twierdzi, iż Lewandowską przywieziono do Starobielska, ponieważ już wówczas nosiła mundur podporucznika. Kto ją mianował na ten stopień - nie wiadomo. Henryka Wolna - Von Das twierdzi, że Lewandowska została rozpracowana przez NKWD. Aby ją chronić przed Sowietami, nadano jej fikcyjny stopień podporucznika lotnictwa i znaleziono dla niej mundur (za duży). Zob. H. Wolna - Von 
obozu w Kozielsku. Przy jej zwłokach nie odnaleziono żadnych zapisków. Jej odwagę w obozie znamy ze wzmianek innych więźniów.

W dramacie Lewandowska jest jedyną kobietą wśród tysięcy więźniów osadzonych w obozie. „Zakwaterowano” ja w schowku pod schodami, aby zapewnić jej minimum prywatności. Współwięźniowie nazywali to miejsce „Bristolem”. W obozie brała czynny udział w życiu konspiracyjnym i religijnym. Przygotowywała hostie do komunii świętej, organizowała obozowe Boże Narodzenie, śpiewała kolędy. „Zrobiłam opłatek. Lichy, ale jest” - powie w dramacie. Pomagała, pocieszała każdego, kto tego potrzebował. Koledzy nazywali ją między soba „Matką Boską Kozielską”.

Matka Boska Kazańska - Janina Lewandowska - w dramacie wchodzi w interakcję z Czapskim. W kolorze niebieskim - ona wspomina skoki spadochronowe: „Niebo takie błękitne dziś. Raz, dwa, trzy! A teraz skacz! [...] Rób fikołki w błękicie. Wiesz, że byłam pierwszą kobieta, która skakała w Polsce ze spadochronem?...”. Czapski: „Najbardziej tęsknię za niebieskim. Nil Błękitny, Lazurowe Wybrzeże...”. Ona: „Patrz w górę!”. On: „Niebieski to tutaj kolor pleśni. Buty zaczynają nam pleśnieć, a od nich skóra” ${ }^{35}$. Ten dialog przerywa Wielka Kłamczucha Katyńska: „Koniec widzenia. [...]. To nie miejsce dla kobiet. Kobiet nie przyjmujemy. [...] Zresztą ty w Kozielsku, on w Starobielsku. Nie macie prawa się znać" ${ }^{36}$.

Druga kwestia, którą Holewińska powierzyła Lewandowskiej, to upomnienie się o inne kobiety zamordowane przez NKWD z „listy ukraińskiej katyńskiej”. W dużej liczbie były to Żydówki. Na „nieludzkiej ziemi” zginęło wiele kobiet. Lewandowska była jedyna, która miała stopień wojskowy; jedyna, która zamordowano w Katyniu. Matka Boska Kazańska stwierdza, że o innych się nie mówi, ponieważ „nie pasują do pięknej historii”; tylko „córka generała nadaje się do przemówień i pomników”. Holewińska w dramacie wymienia kilkanaście nazwisk kobiet z „listy ukraińskiej katyńskiej”.

Historia szczątków Lewandowskiej pokazuje długą i krętą drogę ich identyfikacji. Ciało córki generała Dowbora-Muśnickiego odnaleziono podczas pierwszej ekshumacji w 1943 roku, lecz Niemcy tego nie ujawnili, nie wpisali jej nazwiska na listę ofiar, aby nie „zakłócać jasności przekazu”. Tak powstało pierwsze kłamstwo katyńskie. Profesor Buhtz z Zakładu Medycyny Sądowej we Wrocławiu zabrał czaszki Lewandowskiej i jej sześciu kolegów do badań naukowych. Prawda o zamordowaniu Lewandowskiej w Katyniu

Das, Dziewczyna z Katynia, „Nowa Trybuna Opolska” 15.05.2010. Maria Nurowska pisze, że gen. Henryk Minkiewicz promował Lewandowską na podporucznika pilota w Kozielsku. Zob. M. Nurowska, Pamiętnik znaleziony w Katyniu, Warszawa 2018.

${ }^{34}$ M. Nurowska, op. cit., s. 14.

${ }_{35}$ J. Holewińska, op. cit., s. 22-23.

${ }^{36}$ Ibidem, s. 23. 
wyszła na jaw dopiero po ujawnieniu dokumentów związanych ze zbrodnią katyńską w roku 1990. Szczątki jej czaszki odnaleziono w 2005 roku za sprawa profesora Popielskiego. Droga do ujawnienia prawdy o zamordowaniu Janiny Lewandowskiej w Katyniu także była długa.

Trzeci byt Matki Boskiej Kazańskiej to kobiecość. Lewandowska w obozie była jedyną kobietą wśród tysięcy mężczyzn, dlatego zjawisko pożądania musiało być naturalne. Czuła się jak „szara Kybele” - patronka orgiastycznych obrzędów. Czy podglądają jedyną kobietę w obozie? „Nie, nie podglądaja. Nie zadają też pytań. Ale nie wszyscy. Kilka szarych oficerskich oczu patrzy..." "37 Jeńcy często myślami byli blisko rodzin, matek, żon, narzeczonych, kochanek. Jeden z Tysięcy wspomina: „Moja miała takie czerwone te usta. Najczerwieńsze!”. Drugi z Tysięcy: „Takie miłości, czerwone jak żar, były tylko przed wojną" ${ }^{38}$. Miłość najczęściej jest wyrażana przez kolor czerwony. Czerwień to nie tylko miłość, lecz także kolor krwi. Istotą kobiecości jest menstruacja. „Na wojnie dla kobiet najgorsza jest krew spływająca po nogach"39 - powie Matka Boska Kazańska, ale doda:

Czerwona krew. O czerwonym mówiło się w naszym domu od dziecka. Ale to była inna krew. Nie kobieca. To była czerwień patriotyczna. Przelewana za ojczyznę. [...] Czy menstruacyjną krew można przelać za ojczyznę? Czy kobieca krew przelana za ojczyznę jest tak samo ważna jak męska krew? [...] Kobieca krew nie nadaje się do przelewania. Kobieca krew jest nieczysta ${ }^{40}$.

Na wojnie giną kobiety i mężczyźni, a krew przelana jest jedna, „ojczyźniana" - stwierdzi.

Ostatnią postacią alegoryczną w dramacie Holewińskiej jest wyrazista Wielka Kłamczucha Katyńska. Alegoria tej postaci posłużyła autorce do sportretowania ludzi aparatu władzy wszystkich szczebli oraz pokazania destrukcyjnego systemu sowieckiego i zasad jego funkcjonowania jako całości. Obraz rzeczywistości, czasami wynaturzony, został zbudowany w dramacie z elementów znanych widzowi z historii.

Wielka Kłamczucha Katyńska uosabia system władzy i cały aparat ucisku NKWD. W obozie pełni funkcje nadzorcy, oficera śledczego, a w przyszłości będzie wyrazicielką kłamstwa katyńskiego. Wychwala dobre warunki obozowe, nazywa obóz „Domem Otdycha im. Gorkowa”, zapowiada indoktrynację oraz przemiany ideologiczne i materialne „kuracjuszy”, czyli jeńców.

\footnotetext{
${ }^{37}$ Ibidem, s. 28.

${ }^{38}$ Ibidem, s. 24.

${ }^{39}$ Ibidem, s. 24.

${ }^{40}$ Ibidem, s. 25.
} 
Wszyscy osadzeni byli przesłuchiwani, najczęściej późnym wieczorem i noca. Czapski także przeszedł przez „badania”. We Wspomnieniach starobielskich zaznacza, że nie był szczególnie męczony. W dramacie Katyń. Teoria barw autorka prawie dosłownie przytacza relacje Czapskiego z przesłuchania. Enkawudziści, dość prymitywni, nie mogli zrozumieć tego, że w Paryżu artyści pracowali, tworząc dzieła malarskie. Było to dla nich podejrzane. „Nie mogłem w żaden sposób wytłumaczyć mojemu rozmówcy, że malarze polscy jeżdżacy do Paryża nie byli szpiegami..." - pisze Czapski ${ }^{41}$. W dramacie Holewińska dopisała scenę, której nie ma we Wspomnieniach. Wielka Kłamczucha pyta: „Co robiłeś w Paryżu?”. „Studiowałem kolory” - pada odpowiedź. „Wszystkie wyblakną w mrokach historii” - puentuje Kłamczucha ${ }^{42}$.

Wielka Kłamczucha Katyńska wyśmiewa homoseksualizm Czapskiego, kpi z polskiego antysemityzmu, jeńcom wywożonym na śmierć nakazuje się ogolić. Pozwala na pisanie listów do bliskich - wszystkie były cenzurowane, ale jeńcom „dały poczucie, jakby się zwolniła obręcz naszej samotności” ${ }^{43}$.

Kłamczucha Katyńska występuje z laudacją na cześć wodza Stalina z okazji jego urodzin. W imieniu załogi obozu relacjonuje sytuację jeńców. Czasami bez zrozumienia mówi o warunkach, w jakich więźniowie żyli $\mathrm{w}$ kapitalizmie, innym razem z ironią twierdzi, że jeńcy z „zachwytem podziwiają życie mas pracujących w naszym kraju"44.

Małgorzata Szpakowska zauważa, że postaci Wielkiej Kłamczuchy Katyńskiej dramat Holewińskiej „zawdzięcza coś, co można by nazwać równowaga emocjonalna. Aparat ucisku sprowadzony do rozmiarów groteski stanowi tu przeciwwagę dla elegijnego estetyzmu" ${ }^{45}$ Czapskiego. Kłamczucha jest niekiedy przez Holewińską odrealniana, innym razem jest wulgarna, ale zawsze pełna emocji.

Sztuka Katyń. Teoria barw Julii Holewińskiej została poświęcona bolesnym wydarzeniom historycznym i mimo że podlega rozmaitym zabiegom dramatopisarskim, w swojej wymowie jest poruszająca. Współczesna autorka nie cofa się przed trudnymi i skomplikowanymi tematami, rzutującymi na formę i stylistykę utworu. Dramatyczne wydarzenia historyczne przybierają formę interesującej gry między historią a sztuka, gry, której aktantami są rzeczywiste postaci (Józef Czapski, Janina Lewandowska) oraz alegorie. Być może dzięki takiemu artystycznemu ujęciu bolesna historia będzie mogła wreszcie zaistnieć na scenie w oryginalnym i ciekawym utworze dramatycznym.

\footnotetext{
${ }^{41}$ J. Czapski, op. cit., s. 38.

${ }^{42}$ J. Holewińska, op. cit., s. 22.

${ }^{43}$ J. Czapski, op. cit., s. 36.

${ }^{44}$ J. Holewińska, op. cit., s. 31-32.

${ }^{45}$ M. Szpakowska, op. cit., s. 13.
} 


\section{BIBLIOGRAFIA}

Assmann A., Curtural Memory and Western Civilizacion, Cambridge 2011.

Baluch W., Sugiera M., Zając J., Dyskurs, postać i płeć w dramacie, Kraków 2002.

Czapski J., Wspomnienia starobielskie, [w:] idem, Na nieludzkiej ziemi, Warszawa 1990.

Eco U., Poetyka dzieła otwartego, [w:] idem, Dzieło otwarte. Forma i nieokreśloność w poetykach wspótczesnych, przeł. J. Gałuszka, Warszawa 1994.

Gage J., Kolor i znaczenie. Sztuka, nauka i symbolika, przeł. J. Holzman, A. Żakiewicz, Kraków 2010.

Goethe J.W., Nauka o barwach, przeł. E. Namowicz, [w:] idem, Wybór pism estetycznych, wyb., oprac. i wstęp T. Namowicz, Warszawa 1981.

Goethe J.W., Refleksje i maksymy, oprac. J. Prokopiuk, Warszawa 1977.

Handelsman M., Historyka, oprac. P. Węcowski, reprint, Warszawa 2010.

Hegel G.W.F., Wyktady o estetyce, t. I, przeł. J. Grabowski, A. Landman, Warszawa 1964.

Holewińska J., Katyń. Teoria barw, „Dialog” 2020, nr 12.

Katyń, Andrzej Wajda o filmie, http://www.wajda.pl/pl/filmy/katyn.html (dostęp: 2.05.2021).

Kolor w kulturze, red. Z. Mocarska-Tycowa, J. Bielska-Krawczyk, Torun 2010.

Nurowska M., Pamiętnik znaleziony w Katyniu, Warszawa 2018.

Rzepińska M., Historia koloru w dziejach malarstwa europejskiego, Warszawa 2009.

Rzepińska M., Studia z teorii i historii koloru, Kraków 1966.

Szewczyk-Świerniak D., Polifonie chóralności w najnowszym dramacie polskim, Kraków 2020.

Szkudlarek E., Portrety cieni Witkacego, Poznań 2017.

Szpakowska M., W kolorach, „Dialog” 2020, nr 12.

Tabaszewska J., Kategoria pamięci kulturowej w badaniach nad literatura, „Pamiętnik Literacki" 2013, CIV, z. 4.

Toozi V., Przywileje świadectwa. Historia pamięci i literatura w sporach o konstruowanie nieodległej przeszłości, przeł. E. i J. Zięba, „Teksty Drugie” 2010.

Aleksandra Kosicka-Pajewska - dr hab., prof. UAM. Afiliacja - historia. Autorka książek: Kwintet warszawski. Szkic do portretu zbiorowego stotecznej inteligencji dwudziestego wieku (Poznań 2014), Stanistaw Tarnowski. Szkic do portretu (Poznań 2019; współautorka). ORCID: 0000-0001-7884-0948. Adres e-mail: <aleksandra.kosicka-pajewska@amu.edu.pl>.

Aleksandra Kosicka-Pajewska - PhD (dr hab.), professor of Adam Mickiewicz Unviersity, affiliation - history. Author of the book: Warsaw quintet. Sketch for a collective portrait (Poznań 2014); Co author Stanisław Tarnowski. Sketch for a portrait (Poznań 2019). ORCID: 0000-0001-7884-0948. E-mail address:<aleksandra.kosicka-pajewska@ amu.edu.pl>. 
